\title{
PENGEMBANGAN POLITICAL WILL PEMERINTAH DESA MEMBERDAYAKAN PETANI AREN DI KOTO TUO BARAT KECAMATAN XIII KOTO KAMPAR
}

\author{
Ali Yusri ${ }^{1,}$ Adlin ${ }^{2}$ \\ ${ }^{1,2}$ Jurusan Ilmu Pemerintahan, Fakultas Ilmu Sosial dan Ilmu Politik Universitas Riau \\ Email : Ali.Yusri@unri.ac.id,adlin@unri.ac.id
}

\begin{abstract}
ABSTRAK
Berdasarkan Peraturan Menteri Dalam Negeri Nomor 84 Tahun 2015 Tentang Susunan Organisasi dan Tata Kerja Pemerintahan Desa Pasal 6 ayat 2, dinyatakan bahwa Kepala desa memiliki tugas untuk memberdayakan masyarakat desa. Selanjutnya dalam Pasal 6 ayat 3 poin disebutkan bahwa pemberdayaan tersebut termasuk pemberdayaan dibidang ekonomi. Tanaman Aren mempunyai potensi memberdayakan ekonomi masyarakat desa dengan potensi hasilnya yang jauh lebih tinggi dibandingkan kebun karet maupun sawit. Menurut Asosiasi Aren Indonesia Provinsi Riau, sangat sedikit pemerintah desa yang mau memberdayakan ekonomi masyarakat melalui budidaya Aren. Hal unik terlihat di desa Koto Tuo Barat, berupa sudah ada beberapa orang masyarakat Desa Koto Tuo Barat telah mulai menanam tanaman aren dan pemerintah desa Koto Tuo Barat terlihat mempunyai komitmen memberdayakan masyarakat melalui tanaman aren sebagaimana dimuat dibeberapa media massa. Dengan demikian politicall will pemerintah desa Koto Tuo Barat memberdayakan masyarakat melalui budidaya aren menarik untuk dikaji. Penelitian ini bertujuan menggambarkan sejauhmana polititicall will pemerintah desa yang diukur dengan beberapa indikator. Penelitian menggunakan metode kualitatif yang dilakukan dengan mewawancara pihak terkait yaitu kepala desa dan perangkat desa serta masyarakat Koto Tuo Barat, serta Asosiasi Aren Indonesia Daerah Riau dan Asosiasi Aren Indonesia Daerah Kampar. Selain itu profil desa dan dokumen lainnya digunakan untuk memperkuat temuan penelitian. Temuan penelitian menunjukkan Pemerintah desa Koto Tuo Barat telah memiliki komitmen mengembangkan budidaya aren untuk meningkatkan ekonomi masyarakat diukur dari indikator inisiatif, pilihan kebijakan. Namun masih lemah dalam hal memobilisasi para pihak, komitmen publik dan pengalokasian anggaran yang memadai untuk pengembangan budidaya aren, kemauan belajar dan beradaptasi.
\end{abstract}

Kata Kunci : Politicall will, Pemerintah Desa, Aren

\section{PENDAHULUAN}

Kepala desa memiliki tugas untuk memberdayakan masyarakat desa secara ekonomi. Hal ini dicantumkan dalam Peraturan Menteri Dalam Negeri Nomor 84 Tahun 2015 Tentang Susunan Organisasi dan Tata Kerja Pemerintahan Desa Pasal 6 ayat 2 [1] yang berbunyi :

"Kepala Desa bertugas

Menyelenggarakan Pemerintahan desa, melaksanakan pembangunan, pembinaan kemasyarakatan dan pemberdayaan masyarakat.

Selanjutnya Dalam Pasal 6 ayat 3 poin d, peraturan yang sama dijelaskan : "pemberdayaan masyarakat, seperti tugas sosialisasi dan memotivasi masyarakat dibidang budaya, ekonomi, politik, 
lingkungan hidup, pemberdayaan keluarga, pemuda, olahraga dan karang taruna."

Berdasarkan ketentuan tersebut dapat dipahami bahwa kepala desa diberi tugas oleh negara untuk memberdayakan masyarakat desa di bidang ekonomi.

Salah satu tanaman yang dapat meningkatkan ekonomi masyarakat desa adalah dengan melakukan budidaya tanaman aren sebab aren dinilai lebih menguntungkan di banding tanaman Sawit. Menurut Dewan Pimpinan Wilayah Asosiasi Aren Indonesia wilayah Riau, Muhammadun, hasil 1 hektar aren lebih menguntungkan sepuluh kali lipat dibanding 1 hektar sawit ${ }^{1}[2]$. Hal senada juga diungkapkan akademisi dari universitas Sumatera Utara, Netti Herlina Siregar bahwa berkebun aren lebih menguntungkan dibandingkan berkebun sawit, sebab untuk satu pohon aren dapat menghasilkan puluhan ribu rupiah perharinya, sehingga jika memiliki 100 pohon aren atau 1 hektar kebun aren akan jauh melebihi hasil dari kebun kelapa sawit $^{2}[3]$. Bahkan menurut ketua Yayasan Masarang, Willie Smits, dengan punya 8 pohon aren, seorang petani akan mengantongi pendapatan 4 juta perbulannya ${ }^{3}[4]$. Berdasarkan uraian tersebut dapat disimpulkan bahwa budidaya aren dapat memberdayakan ekonomi masyarakat. Berdasarkan informasi dari pengurus Asosiasi Aren Indonesia wilayah Riau, sangat sedikit pemerintah desa di Riau yang berminat memberdayakan ekonomi masyarakat desa melalui budidaya aren, padahal kemampuan budidaya aren mensejahterakan petani sudah terbukti di beberapa daerah di Indonesia. Padahal pemerintah desa dinilai mampu melakukan hal itu sebab anggaran dana desa dari pemerintah pusat dan alokasi dana desa dari pemerintah kabupaten lumayan besar tiap tahunnya.

Pemerintah Desa Koto Tuo Barat terlihat ada memiliki Komitmen Politik dalam memberdayakan petani melalui budidaya Aren. Sohibul Makzum yang juga merupakan Kepala Desa Koto Tuo Barat, adalah Ketua Dewan Pimpinan Asosiasi Aren Indonesia Daerah Kampar (DPD AAI Kampar) telah menyatakan akan bersinergi dengan Pemerintah Kabupaten Kampar dan berbagai pihak untuk memperkenalkan dan mengembangkan Aren selain karet dan Kelapa Sawit ${ }^{4}$ [5].

Budidaya Tanaman Aren semestinya tidak akan terlalu sulit di kembangkan di desa Koto Tuo Barat. Hal ini disebabkan mayoritas masyarakat Koto Tuo Barat berprofesi sebagai petani, sebagai mana tergambar dalam tabel 1 berikut ini :

Tabel.1. Penduduk Desa Koto Tuo Barat Berdasarkan Mata Pencaharian

\begin{tabular}{|l|l|r|}
\hline NO & $\begin{array}{c}\text { MATA } \\
\text { PENCAHARIAN }\end{array}$ & $\begin{array}{c}\text { JUMLAH } \\
\text { (ORANG) }\end{array}$ \\
\hline 1 & Petani & 1025 \\
\hline 2 & Wiraswasta & 175 \\
\hline 3 & PNS & 50 \\
\hline 4 & Buruh & 9 \\
\hline 5 & Pegawai Swasta & 101 \\
\hline 6 & Ibu Rumah Tangga & 793 \\
\hline 7 & Tidak bekerja & 11 \\
\hline
\end{tabular}

Sumber : Data Desa Koto Tuo Barat Tahun 2014

Berdasarkan tabel 1 dapat dilihat bahwa mayoritas masyarakat bekerja sebagai petani. Dalam hal ini adalah Petani Karet.

Penelitian ini berusaha menggambarkan Pengembangan political will Pemerintah Desa Koto Tuo Barat memberdayakan masyarakat melalui Budidaya Aren.

Secara akademik penelitian ini berguna 
untuk memperkaya bahan ajar mata kuliah Pemberdayaan Masyarakat Desa yang merupakan mata kuliah wajib di jurusan Ilmu Pemerintahan. Selain itu kegunaan praktis penelitian ini, adalah membantu percepatan wujudnya Pemberdayaan ekonomi masyarakat desa. Luaran lainnya adalah laporan akhir, artikel ilmiah di proseding seminar ilmiah level nasional dan terbitnya artikel ilmiah di jurnal nasional.

\section{KERANGKA TEORI}

Para ahli mengemukakan beberapa komponen untuk mendefinisikan Political Will, yaitu $^{5}[6]$ :

1. Pembuat keputusan yang memadai;

2. Pemahaman bersama tentang masalah tertentu dalam agenda bersama;

3. Berkomitmen mendukung;

4. Solusi kebijakan yang secara umum dirasakan dan berpotensi efektif.

Kemudian Derick W. Brinkerhoff mengemukakan setidaknya ada 6 Komponen Political will ${ }^{6}[7]$ yaitu :

1. Inisiatif Pemerintah

2. Pilihan kebijakan/ Program

3. Mobilisasi para Pihak

4. Komitmen Publik dan Alokasi Sumberdaya

5. Keberlanjutan Usaha

6. Belajar dan Berdaptasi

Konsep teori di atas didefinisikan sebagai berikut

1. Inisiatif Pemerintah adalah inisiatif Pemerintah Desa Koto Tuo Barat dalam Memberdayakan masyarakat melalui budidaya Aren.

2. Pilihan kebijakan/ program adalah bentuk kebijakan/ program Pemerintah
Desa Koto Tuo Barat dalam Memberdayakan masyarakat melalui budidaya Aren.

3. Mobilisasi para Pihak adalah kegiatan Pemerintah Desa Koto Tuo Barat membangun sinergi dengan para pihak guna mendukung pemberdayakan masyarakat melalui budidaya Aren.

4. Komitmen Publik dan Alokasi Sumberdaya adalah pengalokasian dana dan sumberdaya lainnya oleh Pemerintah Desa Koto Tuo Barat guna mendukung pemberdayakan masyarakat melalui budidaya Aren.

5. Keberlanjutan Usaha adalah kesinambungan upaya yang dilakukan oleh Pemerintah Desa Koto Tuo Barat guna mendukung pemberdayakan masyarakat melalui budidaya Aren.

6. Belajar dan Berdaptasi adalah kesediaan belajar dan beradaptasi pemerintah desa Koto Tuo Barat guna mendukung pemberdayakan masyarakat melalui budidaya Aren. 


\section{Gambar.1. Kerangka Fikir Penelitian}

\section{Pemerintah Desa \\ 1. Inisiatif Pemerintah \\ 2. Pilihan kebijakan/ program \\ 3. Mobilisasi para Pihak \\ 4. Komitmen Publik Alokasi Sumberdaya \\ 5. Keberlanjutan Usaha \\ 6. Belajar dan Ber daptasi \\ dan}

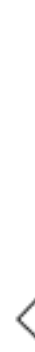
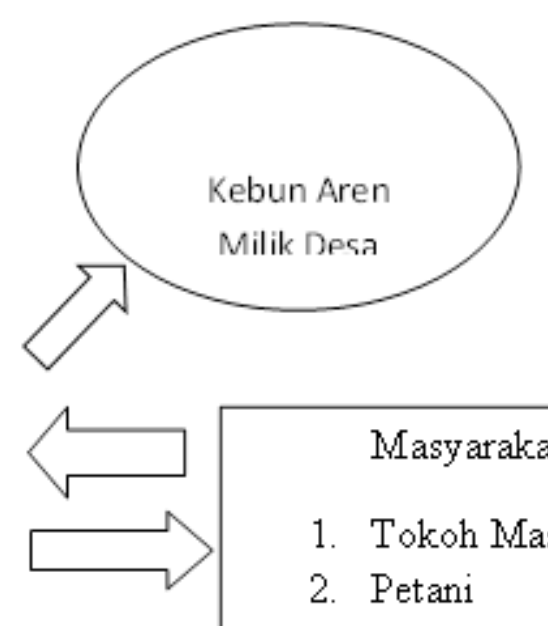

Masyarakat :

1. Tokoh Masyarakat

2. Petani

\section{METODE PENELITIAN}

Metode penelitian yang digunakan adalah metode kualitatif. Lokasi penelitian adalah Instansi Desa Koto Tuo Barat yang penelitian dilaksanakan selama 4 Bulan. Teknik purpossive sampling untuk menentukan informan yang dianggap mempunyai pengetahuan tentang adanya Political will Pemerintah Desa dalam Memberdayakan Masyakat Melalui Budidaya Aren, yaitu Asosiasi Aren Propinsi Riau, Asosiasi Aren Kampar, Kepala Desa Koto Tuo Barat , Perangkat desa Koto Tuo Barat, dan unsur masyarakat. Data yang diambil dalam penelitian ini terdiri dari data primer brupa data yang diperoleh langsung dari informan penelitian melalui proses wawancara. Selanjutnya juga diambil data sekunder berupa data pendukung yang diambil oleh peneliti dari data-data resmi instansi pemerintah maupun non pemerintah serta data dari media massa yang berhubungan dengan penelitian ini.
Teknik pengumpulan data dilakukan dengan dua cara, yakni : 1) Untuk mendapatkan data primer, peneliti akan melakukan wawancara tatap muka dengan menggunakan daftar pertanyaan kepada informan penelitian; 2) untuk mendapatkan data sekunder penelitian, penulis akan mengumpulkan dokumen yang berhubungan dengan pengembangan Political will Pemerintah Desa dalam Memberdayakan Masyakat Melalui Budidaya Aren. Analisa data dilakukan selama proses pengumpulan data dan analisa data dalam penelitian kualitatif menurut Meriam merupakan sebuah proses yang dilakukan secara bersamaan. ${ }^{7}$ [8] Oleh karena itu semua data yang berhasil dikumpulkan dari berbagai sumber yang majemuk berupa wawancara yang dilakukan secara berkesinambungan maupun berupa dokumen, pada saat yang sama akan selalu berusaha diperdalam dianalisa selanjutnya akan digambarkan untuk menghasilkan interprestasi data secara tepat dan akurat. Adapun analisa 
data kualitatif yang akan digunakan adalah analisa data narative sebagaimana diungkapkan Neuman yang meliputi 5 tahap, yakni : 1) sort and classify ; 2) open coding; 3) Axial coding; 4) Selective Coding); 5) interpret \& elaborate. ${ }^{8}$ [9]

\section{HASIL DAN PEMBAHASAN}

\section{A. Keadaan Umum Desa Koto Tuo Barat}

Desa Koto Tuo Barat merupakan pemekaran dari desa Koto Tuo, yang merupakan desa Pemindahan Program Pemerintah Proyek PLTA Koto Panjang. Seiring dengan pesatnya pertumbuhan penduduk dan untuk memudahkan pelayanan masyarakat, maka desa koto Tuo dimekarkan menjadi 2 (dua), yaitu desa Koto Tuo dan Desa Koto Tuo barat. Pemekaran terlaksana di tahun 2005 (desa persiapan) yang dipimpin pejabat sementara kepala desa dan baru defenitif tahun 2008, dengan melaksanakan pemilihan kepala desa di tahun tersebut. Desa Desa koto Tuo Barat memiliki luas wilayah 1.560 ha dengan tata guna lahan yang mayoritas (49\%) digunakan untuk perkebunan rakyat berupa karet dan sawit. Oleh karena itu mata pencaharian rumah tangga di koto Tuo Barat mayoritas sebagai petani pemilik kebun dan buruh tani.

\section{B. Profil Pemerintah Desa Koto Tuo Barat}

Desa Koto Tuo Barat merupakan desa pemekaran sejak tahun 2005, berikut ini di gambarkan pejabat kepala desa/ kepala desa sejak tahun 2005 sampai dengan tahun 2019, yaitu : Abdul Zeri, SP, i, Sohibul Makzum, Arsyad, kembali di pegang Sohibul Makzum dan selanjutnya Rinaldi, SPd.I. Struktur Pemerintah desa dan aparatur desa Koto Tuo Barat tahun 2019, terdiri dari kepala desa,
Rinadi, SPd. I yang membawahi 9 orang perangkat desa, yang terdiri dari sekretaris desa, 4 kepala urusan dan 4 pula kepala Dusun. Mayoritas 80 persen pendidikan terakhir aparatur desa Koto Tuo barat adalah sekolah Menengah Atas/ Sederajat.Hanya 2 orang yang berpendidikan sarjana, yaitu kepala desa Rinaldi, SPd. I dan Kepala Urusan Keuangan, Syafriadi, SP.i. Selanjutnya usia aparatur desa Koto Tuo barat mayoritas (60 persen) berumur 40 tahun kebawah, termasuk kepala desa Rinaldi, SPd.I dan Sekretaris Desa, Taupik.

\section{Gambaran Politicall Will Pemerintah Desa Memberdayakan Petani Aren}

Political will pemerintah menurut Brinkerhoff dapat diukur dengan beberapa indikator. Indikator ini lah yang digunakan untuk mengukur komitmen politik pemerintah desa koto Tuo Barat memberdayakan petani aren yang diuraikan sebagai berikut :

\section{Inisiatif Pemerintah Desa}

Insitiatif memulai mengembangkan Tanaman Aren untuk mengembangkan ekonomi masyarakat desa dimulai oleh kepala desa Koto Tuo Barat tahun 2017, Sohibul Makzum, seperti diungkapkannya sebagai berikut :

"Keinginan mengembangkan tanaman aren di desa Koto Tuo barat ini, memang dimulai dari inisiatif saya pribadi di tahun 2016-2017. Saya melihat tanaman aren ini cocok ditanam di sini dan jika berhasil akan sangat mengangkat kehidupan masyarakat Koto Tuo Barat. Saya mendengar dari pertemuan yang saya ikuti bahwa 1 hektar tanaman aren ini akan menghasilkan uang milyaran setahun”. 
(Wawancara Mei 2019, di rumah Sohibul Makzum)

Berdasarkan wawancara tersebut diketahui bahwa sudah ada Sohibul Makzum secara pribadi aktif dalam kegiatan budidaya aren sekitar tahun 2016-2017. Inisiatif mengembangkan tanaman aren ini ditujukan untuk mengangkat perekonomian masyarakat Koto Tuo Barat agar masyarakat Koto Tuo Barat mendapatkan Penghasilan Milyaran rupiah per tahun.

Dalam rangka mewujudkan ide tersebut Sohibul Makzum dan beberapa orang lainnya membentuk Asosiasi Aren Daerah Kampar, di awal tahun 2017. Sebagaimana diungkap pada Wawancara berikut :

"Untuk merealisasikan keinginan mengembangkan aren di kabupaten Kampar, saya dan beberapa orang membentuk Asosiasi Aren Kabupaten Kampar, yang kebetulan saya dipercaya sebagai ketua nya. Saya berkeinginan mengembangkan aren di Kampar Juga, dengan memulai sosialisasi di Koto Tuo Barat. Akibat sosialisasi tersebut beberapa warga, termasuk saya sendiri menanam pohon aren, walaupun dengan jumlah yang terbatas"

(Wawancara Mei 2019, di rumah Sohibul Makzum)

Hasil wawancara tersebut menjelaskan bahwa inisitif yang dilakukan sohibul makzum yang juga menjabat kepala desa Koto Tuo Barat cukup serius dengan membentuk organisasi pegiat kebun aren level kabupaten. Disisi lain juga giat mensosialisasikan menanam aren di Koto Tuo Barat. Berdasarkan pengamatan kami secara langsung mei 2019, memang aren mulai ditanam oleh masyarakat dalam pekarangan rumahnya, bahkan ada beberapa orang yang menanam aren dalam skala kebun dengan jumlah aren yang di tanam berjumlah ratusan batang.

Inisiatif mengembangkan budidaya aren di Koto Tuo Barat ini mendapat respon yang cukup positif dari kepala desa terpilih, Rinaldi, S,Pd.I yang terpilih pada Pemilihan kepala desa serentak di kabupaten Kampar tanggal 9 November 2017. Sabagaimana dikemukakan Plt Dinas pemberdayaan Masyarakat dan Desa Kabupaten Kampar, bahwa kepala desa terpilih koto Tuo Barat adalah Renaldi ${ }^{9}[10]$.

Adanya respon positif pemerintah desa Koto Tuo Barat memberdayakan ekonomi masyarakat dengan cara menanam tanaman aren terungkap dengan pada wawancara dengan seketaris desa Koto Tuo Barat, Taufik sebagai berikut:

"Pak makzum, telah berinisiatif menanam aren tahun 2016-2017. Namun saat itu belum melibatkan anggaran dan kebijakan level desa. Pemerintah desa Koto Tuo Barat memang tertarik menanam aren mulai tahun 2018 ini. Kami telah merencanakan membuat kebun desa, rencananya di tanam aren telah dicantumkan dalam Rencana Kegiatan Pembangunan Desa tahun 2019”

Berdasarkan wawancara tersebut diketahui bahwa inisiatif masyarakat ditampung dan diterima oleh pemerintah desa Koto Tuo Barat, bahkan telah dimasukan dalam rencana kegiatan pembangunan yang akan dilaksanakan di tahun 2019.

\section{Pilihan Kebijakan/ Program}

Keseriusan Pemerintah Desa Koto Tuo Barat mengembangkan tanaman aren, terlihat dari masuknya Kebun Desa dalam Rencana 
NAKHODA:

JURNAL

ILMU PEMERINTAHAN
NAKHODA: JURNAL ILMU PEMERINTAHAN

Edisi Juli-Desember 2019 Volume: 18 Nomor: 2

ISSN : 1829-5827 |E-ISSN : 2656-5277

DOI : https://doi.org/10.35967/jipn

https://nakhoda.ejournal.unri.ac.id/index.php/JIPN
Kerja Pembangunan Desa (RKPdes) Koto Tuo Barat tahun 2019, yang dapat dilihat pada tabel 1 berikut :

Tabel.2. Rencana Kerja Pembangunan Desa (RKPdes) Koto Tuo Barat tahun 2019

\begin{tabular}{|c|l|c|}
\hline No & \multicolumn{1}{|c|}{$\begin{array}{c}\text { Kegiatan } \\
\text { APBDES }\end{array}$} & Perangkingan \\
\hline 1 & Turap Batu Gunung & 1 \\
\hline 2 & Jalan Setapak & 2 \\
\hline 3 & Semenisasi Dusun III & 3 \\
\hline 4 & Drainase & 4 \\
\hline 5 & $\begin{array}{l}\text { Pembangunan } \\
\text { Lapangan Volly }\end{array}$ & 5 \\
\hline 6 & $\begin{array}{l}\text { Rehab TPA Dusun } \\
\text { IV }\end{array}$ & 6 \\
\hline 7 & Kebun Desa & 7 \\
\hline
\end{tabular}

Sumber data : Dokumen Rencana Kerja Pembangunan Desa (RKPdes) Koto Tuo Barat tahun 2019.

Data Dalam tabel 2 tersebut menunjukkan bahwa pembangunan kebun desa telah masuk dalam rencana kerja pemerintah desa yang akan dilaksanakan di tahun 2019. Menurut sekretaris desa Koto Tuo Barat sebagai berikut :

“ di tahun 2018, kami pemerintah desa untuk membuat perencanaan pembuatan kebun desa yang akan dilaksanakan di tahun 2019. Kebun desa tersebut sudah kami sepakati untuk ditanami aren"

Berdasarkan wawancara tersebut di ketahui bahwa ada komitmen yang cukup kuat dari inisiatif telah di konkritkan dalam bentuk memasukan pembuatan kebun aren untuk desa kedalam dokumen RKPdes tahun 2019.

\section{Mobilisasi Para Pihak}

Mobilisasi para pihak dilakukan secara intensif di tahun 2017 masih dilakukan oleh kepala desa Koto Tuo Barat saat itu, yaitu
Sohibul Makzum, sebagaimana terungkap dalam wawancara dibawah ini :

"Dalam rangka pengembangan tanaman aren ini, saya meloby untuk mendapat dukungan pemerintah kabupaten Kampar. Plt Bupati Kampar saat itu Syahrial Abdi sangat mendukung upaya pengembangan aren di level masyarakat Koto Tuo Barat dan Kampar Umumnya. "

( Wawancara dengan Sohibul Makzum, Mei 2019)

Kegiatan mobilisasi dukungan tersebut didokumentasikan dalam sebuah foto dibawah ini menunjukkan adanya pertemuan, Sohibul Makzum, sebagai ketua AAI Kampar, sekaligus sebagai kepala desa Koto Tuo Barat.

Gambar.2. Konfrensi Pers Pihak Dinas Perkebunan Kampar dengan Sohibul Makzum dan Pengurus AAI Kampar Lainnnya.

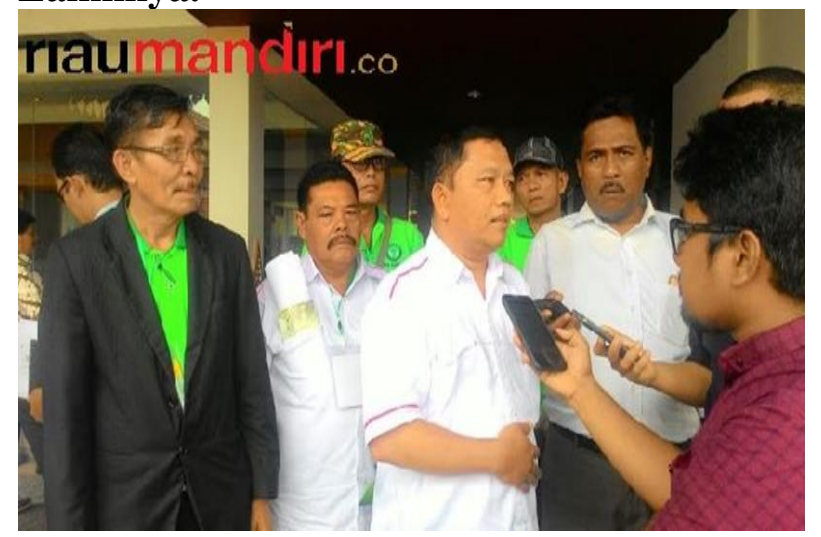

Sumber data : www.riau mandiri.co Tahun 2017

Gambar 2 suasana setelah pertemuan antara sohibul Makzum dari AAI Kampar dan pemerintah Kabupaten Kampar, yang diwakili kepala dinas Perkebunan, Peternakan dan kesehatan hewan, Ir. Bustan pada tanggal 2 
April 2017. Kegiatan tersebut dimuat dalam media online www.riau mandiri.co, yang dimuat 2 april 2017, yang secara secara jelas menerima Sohibul Makzum dan beberapa orang lainnya bertemu dengan pejabat kampar dalam rangka memobilisasi dukungan dari pihak pemerintah Daerah Kabupaten Kampar. Dalam media tersebut disampaikan bahwa pihak pemerintah Kampar Sangat mendukung pengembangan tanaman aren yang di inisiasi oleh Asosiasi Aren Indonesia Daerah Kampar, yang dipimpin oleh Sohibul Makzum, kepala Desa Koto Tuo Barat. ${ }^{\mathbf{1 0}}[11]$

Dukungan pemerintah Kabupaten Kampar tersebut cukup konkrit, sebagaimana diungkapkan oleh Sohibul Makzum sebagai berikut :

“ Pihak Dinas Perkebunan Kampar, Bahkan memberikan sebuah ruangan di salah satu gedung Pemerintah, untuk dijadikan sekretariat Asosiasi Aren Indonesia Daerah Kampar"

( Wawancara dengan Sohibul Makzum, Mei 2019)

Berdasarkan wawancara tersebut diketahui bahwa pemerintah daerah Kampar berkomitmen dengan memberikan ruangan sekretariat untuk AAI Kampar, sebagai sarana mengembang Aren di Kabupaten kampar pada Umumnya.

Namun demikian, dukungan tersebut tidak ditindak lanjuti dengan pengadaan aren bagi masyarakat, akibatnya pengembangan aren tersendat. Sekretariat dan fasilitas lain yang disediakan menjadi tidak termanfaatkan. Walaupun demikian di level desa Koto Tuo Barat, Sohibul Makzum berhasil memotivasi masyarakat menanam aren. Hal ini terungkap pada wawancara dibawah ini :
"Di level kabupaten Kampar, kurang berhasil. Sebab fasilitas yang diberikan tidak dimanfaatkan, sebab biaya operasional mengurus organisasi sangat besar, sehingga saya tidak mampu. Namun di koto Tuo Barat, cukup berhasil ditandai dengan cukup banyaknya masyarakat yang tertarik dan menanam aren"

(Wawancara dengan Sohibul Makzum Mei 2019)

Berdasarkan wawancara tersebut diketahui bahwa masyarakat sebagai salah satu stake holders Pembangunan di Koto Tuo barat cukup mendukung Pengembangan budidaya aren di desa tersebut.

Hal senada juga diungkapkan sekretaris Desa Koto Tuo Barat Sebagai berikut :

"Pak Sohibul Makzum, telah memotivasi masyarakat menanam aren dengan pola tanam di pekarangan Rumah, bahkan ada juga warga yang menanam aren dengan jumlah banyak" ( Wawancara, dengan Taufik, sekretaris desa Koto Tuo Barat, 2019)

Hasil wawancara ini diperkuat dengan observasi lapangan oleh peneliti bahwa aren memang mulai di tanam warga di pekarangan rumahnya dan peneliti juga melihat langsung ada warga yang menanam aren dalam skala kebun dengan jumlah tanaman aren lebih dari 100 pohon yang ditumpangsarikan dalam kebun kelapa sawit.

Dalam hal mobilisasi para pihak untuk meningkatkan tanaman aren telah dimulai pihak pemerintah desa Koto Tuo Barat, sebagai berikut : 
NAKHODA:

JURNAL

ILMU PEMERINTAHAN
NAKHODA: JURNAL ILMU PEMERINTAHAN

Edisi Juli-Desember 2019 Volume: 18 Nomor: 2

ISSN : 1829-5827 | E-ISSN : 2656-5277

DOI : https://doi.org/10.35967/jipn

https://nakhoda.ejournal.unri.ac.id/index.php/JIPN
" beberapa langkah yang telah kami mulai juga diantara menjalin komunikasi dengan pak Sohibul Makzum, yang mengetahui tentang pengadaan bibit aren yang nantinya bisa digunakan untuk kebun desa, maupun untuk dibagikan ke masyarakat sebagai salah satu program desa Koto Tuo Barat".

( Wawancara dengan Taupik, Sekdes Koto Tuo Barat Mei 2019)

Berdasarkan wawancara tersebut mobilisasi para pihak telah dilakukan dengan pihak yang berkompeten mengadakan bibit aren. Namun demikian kegiatan memobilisasi dukungan dari pihak lainnya belum dilakukan oleh pemerintah desa. Pihak terkait itu misalnya dinas perkebunan kabupaten Kampar, yang mungkin juga punya program membagikan bibit tanaman kepada masyarakat di Kampar. Jika koordinasi dan dukungan pemerintah kabupaten didapatkan, tentu pengembangan ekonomi masyarakat desa melalui budidaya pohon aren bisa bergerak lebih cepat dan masif.

\section{Komitmen Publik dan Alokasi Sumber Daya \\ Komitmen pemerintah desa Koto Tuo}

Barat, pimpinan Rinaldi SPd,I telah terlihat secara kelembagaan yang dibuktikan dengan telah dibuatnya Rencana Kerja Pembangunan Desa Koto Tuo Barat, berupa pembuatan kebun desa yang akan dilaksanakan di tahun 2019. Kebun desa yang akan dibuat tersebut akan ditanami aren. Hal ini terungkap dalam wawancara dibawah ini :

" Kebun Desa Tersebut akan kami tanami Aren, sebagai inovasi desa Koto Tuo Barat. Beberapa warga telah mulai menanam aren, akan kami tingkatkan dengan membuat kebun aren desa pada tahap awal seluas 4 hektar"

(wawancara dengan sekretaris Desa Koto Tuo Barat, Taupik, Mei 2019)

Berdasarkan wawancara tersebut, diketahui bahwa pemerintah desa koto tuo Barat, telah berencana mengalokasikan sumberdaya berupa tanah seluas 4 hektar untuk dijadikan kebun desa Koto Tuo Bara Selanjutnya komitmen tersebut, belum begitu kuat, hal ini terlihat dalam rencana kerja pembangunan desa yang merupakan prioritas terakhir dalam dokumen tersebut. Kesimpulan tersebut juga terungkap dalam wawancara berikut ini :

" penganggaran dana pembuatan kebun desa akan dilakukan dalam perubahan Anggaran Pendapatan dan Belanja Desa di akhir tahun 2019."

(wawancara dengan Sekretaris Desa Koto Tuo Barat, Taupik, Agustus 2019)

Hasil wawancara tersebut menunjukkan bahwa pembuatan kebun desa tidak dianggarkan dalam pendapatan belanja desa yang murni, yang biasanya dilaksanakan di awal tahun. Dengan demikian dapat disimpulkan indikator penyediaan alokasi anggaran belum diprioritaskan dibandingkan renca kegiatan pembangunan desa lainnya.

\section{Keberlanjutan Usaha}

Upaya memberdayakan masyarakat oleh pemerintah melalui budidaya aren tetap berlanjut dengan berbagai dinamikanya. Di masa kepemimpinan kepala desa Rinaldi, Spdi, tahun 2018 sampai 2019 komitmen pemerintah desa terus berkembang dengan memasukan rencana membuat kebun aren untuk desa. 
Bahkan pemerintah desa juga berencana membuka pembibitan aren genjah, sebagai salah satu program inovasi desa Koto Tuo Barat. Sebagaimana terungkap pada wawancara berikut ini :

" dalam rangka membuat kebun aren desa, kami juga berencana membuat pembibitan aren untuk memasok bibit ke kebun desa dan mengedarkan ke masyarakat. Bahkan tidak mungkin di jual sebagai sumber pemasukan bagi desa"

( Wawancara dengan sekdes Koto Tuo Barat, Taupik, 2019)

Berdasarkan wawancara tersebut dapat diketahui bahwa upaya memberdayakan desa dan masyarakat desa terus dilakukan oleh pemerintah koto Tuo Barat, mulai dengan merencanakan membuat kebun desa, membuat pembibitan aren sebagai inovasi desa, bahkan melakukan aktivitas penjualan bibit aren sebagai salah satu sumber penerimaan asli desa (PADes).

\section{Kemauan Belajar dan Beradaptasi}

Kegiatan belajar mencari informasi tentang budidaya aren oleh pemerintah desa tahun 2018-2019 masih terbatas. Kegiatan belajar dan beradaptasi lebih banyak dilakukan oleh, Sohibul Makzum kepala desa koto Tuo Baratdi tahun 2016-2017. Hal ini terungkap dalam wawancara sebagai berikut :

"Saya memang antusias mencari informasi dan belajar mengenai tanaman aren ini. Saya pernah mengikut pertemuan asosiasi Aren Se Indonesia di Pekanbaru yang didukung oleh pemerintah provinsi Riau. Saya pernah berkunjung ke Kalimantan melihat bagaimana Budidaya Aren, bahkan saya juga pernah berkunjung ke kebun aren yang di Palas Pekanbaru, yang menghasilkan 40 juta rupiah perbulan untuk 200 pohon aren".

( Wawancara dengan Sohibul Makzum, mei 2019)

Berdasarkan wawancara tersebut diketahui bahwa sohibul Makzum yang menjabat kepala desa Koto Tuo Barat di tahun 2016 dan 2017 mempunyai kemauan yang tinggi untuk mempelajari budidaya tanaman aren dan mengembangkan kannya di Koto Tuo Barat khususnya dan Kampar Umumnya. Dalam kegiatan belajar tersebut Sohibul Makzum menjelaskan :

“ Dalam upaya belajar mencari informasi tersebut, saya berkesimpulan tanaman aren sangat prospek di kembangkan di Koto Tuo Barat, dan kampar Umumnya. Bahkan menurut penjelasan pihak kementerian, bahwa tidak perlu khawatir dengan pemasaran gula aren, permintaan pasar sangat tinggi, sementara kemampuan indonesia memasok sangat kecil, sehingga peluang budidaya aren untuk memberdayakan ekonomi masyarakat desa sangat terbuka."

( Wawancara dengan Sohibul Makzum, Mei 2019)

Berdasarkan wawancara tersebut diketahui bahwa dari proses belajar dan mencari informasi tersebut, keinginan mensosialisasikan tanaman aren ke masyarakat semakin tinggi dalam rangka memberdayakan ekonomi masyarakat Koto Tuo Barat dan Kampar pada umumya. Proses adaptasi juga terjadi sebab tentu tidak semua masyarakat Koto Tuo Barat yang paham untuk mencoba 
budidaya aren. Hal ini terungkap pada wawancara dibawah ini :

"kendala mengembangkan aren di koto Tuo Barat adalah masyarakat belum begitu yakin dengan tanaman aren. Oleh karena itu saya beradaptasi dengan meyakinkan keluarga dekat saya terlebih dahulu dan tetangga untuk menanam aren di pekarangan rumah masingmasing"

( wawancara dengan Sohibul Makzum, Mei 2019)

Berdasarkan wawancara tersebut, sohibul makzum melakukan adaptasi sebagai upaya tetap mengembangkan komitmen mengembangkan aren dengan mengarahkan anggota keluarga dan tetangganya untuk menanam pohon aren dengan pola agregat, yaitu dengan menanam di pekarangan rumah masing-masing.

Kegiatan belajar dan beradaptasi mengenai pengembangan budidaya aren oleh pemerintah desa dalam rangka meningkatkan ekonomi masyarakat, belum serius dilakukan oleh pemerintah desa Koto Tuo Barat. Hal ini dapat dilihat dengan belum adanya kegiatan pendidikan, studi banding, kunjungan pemerintah desa kepada pihak-pihak yang berkompeten melakukan pengembangan budidaya aren sebagaimana yang dilakukan warga masyarakat, Sohibul Makzum.

\section{KESIMPULAN}

Pemerintah desa Koto Tuo Barat telah memiliki komitmen mengembangkan budidaya aren untuk meningkatkan ekonomi masyarakat diukur dari indikator inisiatif, pilihan kebijakan. Namun masih lemah dalam hal memobilisasi para pihak, komitmen publik dan pengalokasian anggaran yang memadai untuk pengembangan budidaya aren, kemauan belajar dan beradaptasi.

\section{DAFTAR PUSTAKA}

Asim Mujkić, "AN INTRODUCTION TO POLITICAL WILL," in Political will: a short introduction Case study - Bosnia and Herzegovina, 2015.

D. W. Brinkerhoff, "Unpacking the concept of political will to confront corruption," $U 4$ Brief. 2010.

J. W. Creswell, Desain Penelitian : Pendekatan Kualitatif \& Kuantitatif. Jakarta: KIK Press 160, 2002.

W. L. Neuman, Social Research Methods: Qualitative and Quantitative Approaches. 2011.

\section{Peraturan Perundangan}

Peraturan Menteri Dalam Negeri, Nomor 84 Tahun 2015 Tentang Susunan Organisasi dan Tata Kerja Pemerintahan Desa.

\section{Sumber Internet}

Goriau.com, "“ Panen Aren 10 Kali Untung dari Kelapa Sawit, Masyarakat Siak Mulai Lirik ini'. Akses 17 Maret 2019," (https://www.goriau.com/berita/baca/pa nen-aren-10-kali-untung-dari-kelapasawit-masyarakat-siak-mulai-lirikini.html). .

finance. Detik.com, “" Penasihat Energi Prabowo sebut Petani Aren Bisa Raup Rp 4 juta / bulan'. Akses 18 Maret 2019.," 
(https://finance.detik.com/energi/d2597377/penasihat-energi-prabowosebut-petani-aren-bisa-raup-rp-4jutabulan).

News. Analisadaily.com, "“" Aren diklaim Lebih Menguntungkan dibanding Kelapa Sawit ". Akses 18 Maret 2019.," (http://news.analisadaily.com/read/arendiklaim-lebih-menguntungkan-darikelapa-sawit/225620/2016/03/29).

Riau Mandiri. Co., “" Pemda Kampar Dukung Budidaya Tanaman Aren Oleh AAI'. Akses 18 Maret 2019.," (https://www.riaumandiri.co/news/detail/ 50930/pemda-kampar-dukung-budidayatanaman-aren-oleh-aai.html).

\section{ENDNOTE}

${ }^{1}$ Goriau.com. " Panen Aren 10 Kali Untung dari Kelapa Sawit, Masyarakat Siak Mulai Lirik ini”. Akses 17 Maret 2019 (https://www.goriau.com/berita/baca/panen-aren-10kali-untung-dari-kelapa-sawit-masyarakat-siak-mulailirik-ini.html)

${ }^{2}$ News. Analisadaily.com. “ Aren diklaim Lebih Menguntungkan dibanding Kelapa Sawit “ . Akses 18 Maret 2019. (http://news.analisadaily.com/read/arendiklaim-lebih-menguntungkan-dari-kelapasawit/225620/2016/03/29)

3 finance. Detik.com. " Penasihat Energi Prabowo sebut Petani Aren Bisa Raup Rp 4 juta / bulan”. Akses 18 Maret 2019. (https://finance.detik.com/energi/d2597377/penasihat-energi-prabowo-sebut-petani-arenbisa-raup-rp-4-jutabulan)

${ }^{4}$ Riau Mandiri. Co. " Pemda Kampar Dukung Budidaya Tanaman Aren Oleh AAI". Akses 18 Maret 2019. (https://www.riaumandiri.co/news/detail/50930/pemdakampar-dukung-budidaya-tanaman-aren-oleh-aai.html)

${ }^{5}$ Dino Abazovic, Asim mujkic (ed), 2015. Politicall

Will: A short Case Study-Bosnia and Herzegovina.

Sarajevo : FES., 14

${ }^{6}$ https://www.u4.no/publications/unpacking-the-conceptof-political-will-to-confront-corruption.pdf

\footnotetext{
${ }^{7}$ John W. Creswell. 2002. Desain Penelitian: Pendekatan Kualitatif \& Kuantitatif. Jakarta: KIK Press,. 160.

${ }^{8}$ Neuman, W. Lawrence, 2003. Social Research Methods: Qualitative and Quantitative Approaches. Boston : Perason Education, Inc, hal 448.

${ }^{9}$ Tribunpekanbaru.com "ini Kades Terpilih, Pilkades Serentak di Kampar", akses 1 Agustus 2019.(https://pekanbaru.tribunnews.com/2017/11/24/inikades-terpilih-pilkades-serentak-di-kampar)

10 "Pemda Kampar Dukung Budidaya Aren Oleh AAI". Akses 2 Agustus 2019

(https://www.riaumandiri.co/news/detail/50930/pemdakampar-dukung-budidaya-tanaman-aren-oleh-aai.html)
} 